BIOMEDICAL AND BIOSOCIAL ANTHROPOLOGY
Official Journal of the International Academy
of Integrative Anthropology
journal homepage: http://bba-journal.com

\title{
Features of hemostasis disorders in patients with CKD VD stage and their relationship with the course of the disease
}

Storozhuk O. B. ${ }^{1}$, Shevchuk S. V. ${ }^{1}$, Storozhuk L. O. ${ }^{2}$, Dovgalyuk T. V. ${ }^{2}$, Storozhuk B. G. ${ }^{1}$

${ }^{1}$ SRI for Rehabilitation of Persons with Disabilities of National Pirogov Memorial Medical University, Vinnytsya, Ukraine ${ }^{2}$ National Pirogov Memorial Medical University, Vinnytsya, Ukraine

\section{ARTICLEINFO}

Received: 7 June, 2019

Accepted: 15 July, 2019

UDC: $612.115: 616.61-008.64-036.17-$ 052

\section{CORRESPONDING AUTHOR}

e-mail: stgibson91@gmail.com

Storozhuk O. B.
Disorders in the hemostatic system leading to the development of thrombosis are one of the main complications in patients with chronic kidney disease (CKD) of stage VD who are on program hemodialysis. The development of thrombophilic syndrome as a process of intravascular coagulation is characterized by systemic activation of procoagulative mechanisms, which are not always compensated by internal natural anticoagulant systems. The determination of early predictors of possible thrombogenesis in the studied category of patients causes significant difficulties. The goal is to study the features of hemostatic system disorders in patients with CKD VD stage who are on programmed hemodialysis, and to assess their relationship with the characteristics of the course of the disease. In 88 patients with CKD of the VD stage who are on program hemodialysis (52 men and 36 women), the features of hemostasis disorders depending on the clinical characteristics of the patients were studied. The indicators of prethrombosis (soluble fibrin $(s F)$, fibrinogen $(F g)$, functionally inactive forms of prothrombin (FIFP)), postthrombosis (D-dimer (D-d)) and anticoagulation (protein $C(p C)$ ) were determined depending on gender, hemodialysis experience, age, the presence of anemia, arterial hypertension $(A H)$ and preserved residual renal function $(R R F)$. Statistical processing of materials was carried out using methods of variation statistics using t-student criterion. It was found that violations in the hemostatic system are detected in almost all patients. At the same time, hyperfibrinogenemia, an increase in $s F$ concentration, a deficiency of $p C$, less often an accumulation of FIFP and high levels of $D$ - $d$ are most often observed. These disorders of hemostasis are more often found in patients with absent RRF, a longer experience of hemodialysis, the presence of arterial hypertension and are less associated with gender, age of patients and are little dependent on the degree of anemia.

Keywords: CKD stage VD, hemodialysis, hemostasis, soluble fibrin, D-dimer, fibrinogen, protein $C$, forms of prothrombin are functionally inactive.

\section{Introduction}

Disorders in the hemostasis system, which lead to the development of thrombosis, are one of the main complications of patients with chronic kidney disease (CKD) stage VD, who are on program hemodialysis [10]. The development of thrombophilic syndrome as a process of intravascular coagulation is characterized by systemic activation of procoagulant mechanisms, which are not always compensated by internal natural anticoagulant systems [16]. Determining the early predictors of possible thrombogenesis in the studied category of patients causes significant difficulties. The latter is related, inter alia, to the individual clinical characteristics of patients. In this regard, the assessment of hemostasis should be based on a comprehensive analysis of hemostasis, which most objectively characterizes the processes of blood clotting, and the clinical characteristics of patients (sex, age, experience on hemodialysis, hypertension and anemia, preserved residual renal function (RRF)). It is known that one of the main proteins of the blood coagulation system is a glycoprotein - fibrinogen $(\mathrm{Fg})$, which under the action of thrombin is converted into fibrin with the formation of fibers that form the basis of the clot [5]. In the process of clot formation and cleavage, the two most important molecular markers for assessing the state of hemostasis are soluble fibrin (sF) and D-dimer (Dd) [7, 18]. In this case, it is also necessary to consider the potential of a natural blood 
clotting inhibitor, which is protein $C(p C)$ [20] and the accumulation index of functionally inactive forms of prothrombin (FIFP) [19]. To determine the potential suitability of activators and inhibitors of thrombogenesis as markers of thrombophilia, a study of markers of prethrombosis - Fg, sF, FIFP, postthrombosis - D-d and natural anticoagulant protein $C$ in different groups of patients with CKD stage VD treated by program hemodialysis.

The aim of the work is to study the features of hemostasis disorders in patients with CKD stage VD who are on program hemodialysis and to evaluate their connection with the peculiarities of the disease.

\section{Materials and methods}

In accordance with the principles of biomedical ethics, on the basis of informed consent, we examined 88 patients with CKD stage VD who receive renal replacement therapy by programmed hemodialysis (52 men and 36 women). 20 practically healthy persons served as control. Blood samples of examined patients and practically healthy individuals for plasma production were taken on an empty stomach from a vein, without the use of a tourniquet, in a vacutainer with $3.8 \%$ sodium citrate solution and mixed in a ratio of 1:9. The deposition of formed blood elements was performed by centrifugation for 20 minutes with an acceleration of $1200-1400 \mathrm{~g}$.

The concentration of sF (marker of activation of the blood coagulation system) was determined using the method of bi-site ELISA for the cleavage of fibrin plasmin cleavage products [6]. Determination of the level of $D$ was performed by ELISA assay using monoclonal antibodies to epitopes of D-dimers, which are formed only by cleavage of insoluble fibrin by plasmin [8]. The activity of protein $\mathrm{C}$ in blood plasma was determined spectrophotometrically, activating it with the venom of the Gloydius halys (Agkistrodon halus halus) [2]. Determination of fibrinogen content in blood plasma was performed using the thrombin-like enzyme ancistron$\mathrm{H}$, obtained from the venom of the Gloydius halys (Agkistrodon halus halus) by spectrophotometric method [14]. Calculations were performed according to the formula: $\mathrm{Fg}=(\mathrm{E} 280-\mathrm{E} 320) \times 255 / 15.06$, where $\mathrm{Fg}$ is the concentration of fibrinogen in blood plasma in $\mathrm{g} / \mathrm{l} ; 255$ coefficient for converting the content of fibrinogen in the volume of the sample to its concentration in plasma; 15.06 - absorption extinction coefficient of $1 \%$ solution of fibrin in an acidic environment at a wavelength of $280 \mathrm{~nm}$ [8].

Thromboplastin was used to determine the prothrombin time (external pathway of the blood coagulation system), and the prothrombin index was calculated as the ratio of the prothrombin time of the studied plasma to the prothrombin time of healthy donors [17].

To determine the ecamulin time used ecamulin - the enzyme activator of prothrombin, isolated from the venom of Echis multisquamatis. The ecamulin index was defined as the ratio of the ecamulin time of the studied plasma to the ecamulin time of healthy donors [17].
The accumulation index of decarboxylated FIFP was calculated as the ratio between ecamulin and prothrombin indices based on predetermined quantitative patterns of FIFP content [19].

Statistical processing of materials was performed using the methods of variation statistics using Student's t-test.

\section{Results}

It was found that in patients with CKD stage VD with a high $(95.5 \%)$ frequency, disorders in the hemostasis system were registered, which was characterized by increased levels of fibrinogen, soluble fibrin, D-dimer, accumulation of FIFP and decreased protein C. In the control group revealed disorders in the hemostasis system were observed only in $45.0 \%$ of cases (Table 1). In particular, the average level of fibrinogen in the studied patients was $89.0 \%$ higher compared to the control, and the share of persons with hyperfibrinogenemia was more than 13 times higher. Many patients showed signs of activation of the blood coagulation system, which was manifested in an increase in average concentrations of soluble fibrin by $43.0 \%$ and more than a 2-fold increase in the number of individuals with high levels of the studied indicator. High serum levels of D-dimer were found in $20.5 \%$ of patients, while in the control group there were only $5.0 \%$. Similar trends are observed in patients with FIFP, in whom this indicator was elevated in $45.5 \%$, while in the control group such cases were not observed. Compared with healthy individuals, there was a significant decrease in the activity

Table 1. Indices of hemostasis in patients with CKD stage VD and controls.

\begin{tabular}{|l|c|c|}
\hline \multicolumn{1}{|c|}{ Indices of hemostasis } & $\begin{array}{c}\text { Control group } \\
\mathrm{n}=20\end{array}$ & $\begin{array}{c}\text { Patients with CKD } \\
\text { stage VD } \mathrm{n}=88\end{array}$ \\
\hline $\mathrm{sF}, \mu \mathrm{g} / \mathrm{ml}$ & $2.603 \pm 0.312$ & $3.721 \pm 0.190^{*}$ \\
\hline $\begin{array}{l}\text { Proportion of persons with } \\
\mathrm{sF} \geq 3,0 \mu \mathrm{g} / \mathrm{ml}\end{array}$ & $6(30.0 \%)$ & $60(68.2 \%)^{*}$ \\
\hline $\mathrm{D}-\mathrm{d}, \mathrm{ng} / \mathrm{ml}$ & $70.04 \pm 9.10$ & $75.33 \pm 7.31$ \\
\hline $\begin{array}{l}\text { Proportion of persons with } \\
\text { D-d }>105 \mathrm{ng} / \mathrm{ml}\end{array}$ & $1(5.0 \%)$ & $18(20.5 \%)^{*}$ \\
\hline Fg, $\mathrm{mg} / \mathrm{ml}$ & $2.202 \pm 0.251$ & $4.162 \pm 0.121^{*}$ \\
\hline $\begin{array}{l}\text { Proportion of persons with } \\
\text { Fg }>2,6 \mathrm{mg} / \mathrm{ml}\end{array}$ & $1(5,0 \%)$ & $82(93.2 \%)^{\#}$ \\
\hline $\begin{array}{l}\text { Proportion of persons with } \\
\text { Fg >3,5 mg/ml }\end{array}$ & $1(5.0 \%)$ & $57(64.7 \%)^{*}$ \\
\hline pC, \% & $98.90 \pm 7.88$ & $81.81 \pm 1.67^{*}$ \\
\hline $\begin{array}{l}\text { Proportion of people with deficits } \\
\text { of pC }<85 \%\end{array}$ & $7(35.0 \%)$ & $50(56.8 \%)^{*}$ \\
\hline FIFP, \% & $99.51 \pm 2.03$ & $109.4 \pm 2.2^{*}$ \\
\hline $\begin{array}{l}\text { Proportion of persons with level } \\
\text { FIFP >110 \% }\end{array}$ & - & $40(45.5 \%)$ \\
\hline No violations & $11(55.0 \%)$ & $4(4.5 \%)^{*}$ \\
\hline
\end{tabular}

Notes: ${ }^{*}$ - probable differences in the control group on average values; \# - the significance of the differences, calculated according to Fisher's exact method for the control group. 
Table 2. Relationship of disorders in the hemostasis system in patients with CKD stage VD with the course of the disease.

\begin{tabular}{|c|c|c|c|c|c|c|}
\hline \multirow{2}{*}{ Groups of patients } & \multirow{2}{*}{$\mathrm{n}$} & \multicolumn{5}{|c|}{ Indices of hemostasis } \\
\hline & & $\mathrm{sF}, \mu \mathrm{g} / \mathrm{ml}$ & $\mathrm{D}-\mathrm{d}, \mathrm{ng} / \mathrm{ml}$ & $\mathrm{Fg}, \mathrm{mg} / \mathrm{ml}$ & $\mathrm{pC}, \%$ & FIFP, \% \\
\hline Control & 20 & $2,603 \pm 0,312$ & $70,04 \pm 9,10$ & $2,202 \pm 0,251$ & $98,90 \pm 7,88$ & $99,51 \pm 2,03$ \\
\hline Patients with CKD stage VD & 88 & $3,721 \pm 0,190^{*}$ & $75,33 \pm 7,31$ & $4,162 \pm 0,121^{*}$ & $81,81 \pm 1,67^{*}$ & $109,4 \pm 2,2^{*}$ \\
\hline \multicolumn{7}{|c|}{ Sexual features } \\
\hline $\begin{array}{l}\text { Men } \\
\text { Women }\end{array}$ & $\begin{array}{l}52 \\
36\end{array}$ & $\begin{array}{l}3.520 \pm 0.151 \\
3.992 \pm 0.413\end{array}$ & $\begin{array}{l}62.04 \pm 4.47 \\
94.50 \pm 16.31\end{array}$ & $\begin{array}{l}4.162 \pm 0.152 \\
4.151 \pm 0.213\end{array}$ & $\begin{array}{l}80.72 \pm 2.02 \\
83.44 \pm 2.85\end{array}$ & $\begin{array}{l}108.2 \pm 2.7 \\
111.1 \pm 3.8\end{array}$ \\
\hline \multicolumn{7}{|c|}{ Relationship with the age of patients } \\
\hline $\begin{array}{l}\text { Youth } \\
\text { Middle } \\
\text { Mature } \\
\text { Sloping }\end{array}$ & $\begin{array}{c}8 \\
26 \\
40 \\
14\end{array}$ & $\begin{array}{l}3.713 \pm 0.574 \\
3.682 \pm 0.304 \\
3.523 \pm 0.161 \\
4.364 \pm 0.910\end{array}$ & $\begin{array}{c}104.0 \pm 56.3 \\
72.93 \pm 14.39 \\
69.81 \pm 6.55 \\
79.20 \pm 11.23\end{array}$ & $\begin{array}{r}4.253 \pm 0.490 \\
3.821 \pm 0.211 \\
4.153 \pm 0.170 \\
4.764 \pm 0.373\end{array}$ & $\begin{array}{l}84.03 \pm 6.19 \\
77.50 \pm 3.23 \\
83.14 \pm 2.46 \\
84.91 \pm 3.46\end{array}$ & $\begin{array}{l}107.8 \pm 7.2 \\
114.4 \pm 4.5 \\
107.0 \pm 3.0 \\
107.9 \pm 5.9\end{array}$ \\
\hline \multicolumn{7}{|c|}{ Connection with stay on hemodialysis } \\
\hline $\begin{array}{l}\text { Up to } 5 \text { years } \\
6-10 \text { years } \\
11-15 \text { years } \\
>15 \text { years }\end{array}$ & $\begin{array}{c}32 \\
34 \\
16 \\
6\end{array}$ & $\begin{array}{l}3.502 \pm 0.261 \\
3.770 \pm 0.393 \\
3.661 \pm 0.210 \\
4.732 \pm 0.781\end{array}$ & $\begin{array}{c}75.52 \pm 15.41 \\
68.22 \pm 6.37 \\
73.60 \pm 21.33 \\
104.5 \pm 12.8\end{array}$ & $\begin{array}{l}4.030 \pm 0.221 \\
4.221 \pm 0.180 \\
4.133 \pm 0.281 \\
4.572 \pm 0.601\end{array}$ & $\begin{array}{c}86.51 \pm 2.82 \\
81.04 \pm 2.57 \\
79.02 \pm 3.61 \\
68.73 \pm 5.54^{\#}\end{array}$ & $\begin{array}{c}104.1 \pm 3.2 \\
111.5 \pm 3.8 \\
111.1 \pm 5.4 \\
120.9 \pm 7.0^{\#}\end{array}$ \\
\hline \multicolumn{7}{|c|}{ Relationship with residual renal function } \\
\hline $\begin{array}{l}\text { Present } \\
\text { Absent }\end{array}$ & $\begin{array}{l}16 \\
72\end{array}$ & $\begin{array}{c}3.061 \pm 0.232 \\
3.863 \pm 0.220^{\#}\end{array}$ & $\begin{array}{c}59.31 \pm 12.52 \\
78.92 \pm 8.47\end{array}$ & $\begin{array}{l}3.640 \pm 0.261 \\
4.271 \pm 0.140^{\#}\end{array}$ & $\begin{array}{l}89.22 \pm 4.10 \\
80.43 \pm 1.75^{\#}\end{array}$ & $\begin{array}{c}100.5 \pm 3.8 \\
110.7 \pm 2.5^{\#}\end{array}$ \\
\hline \multicolumn{7}{|c|}{ Connection with the presence of $\mathrm{AH}$} \\
\hline $\begin{array}{l}\text { Present } \\
\text { Absent }\end{array}$ & $\begin{array}{l}64 \\
24\end{array}$ & $\begin{array}{c}3.884 \pm 0.250 \\
3.291 \pm 0.152^{\#}\end{array}$ & $\begin{array}{c}52.82 \pm 5.01 \\
83.80 \pm 9.69^{\#}\end{array}$ & $\begin{array}{l}3.641 \pm 0.260 \\
4.094 \pm 0.140\end{array}$ & $\begin{array}{l}82.32 \pm 3.01 \\
81.60 \pm 2.01\end{array}$ & $\begin{array}{l}114.8 \pm 5.2 \\
107.4 \pm 2.3\end{array}$ \\
\hline
\end{tabular}

Notes: sF - soluble fibrin; D-d - D-dimer; Fg - fibrinogen; pC - protein C; FIFP - functionally inactive forms of prothrombin; RRF - residual renal function. * - probable differences in the control group on average values. \# - probable differences in patients with the lowest hemodialysis experience, preserved RRF and no $\mathrm{AH}$.

of the natural anticoagulant protein C (by $20.9 \%$ ). The share of persons with its deficit in the main group was $56.8 \%$, in the control group - only $35.0 \%$.

In the next part of the study, an analysis of the identified disorders in the hemostasis system depending on the course of the disease was performed (Table 2). The study did not reveal sex differences in the frequency of disorders and the average values of the analyzed indicators of the hemostasis system. With regard to age, in the youngest age group, as in middle-aged and older patients, approximately the same values of soluble fibrin, fibrinogen, FIFP, D-dimer and protein C were observed. Disturbances in the hemostasis system in patients with CKD stage VD were associated. over time on hemodialysis. In parallel with its increase in serum levels, FIFP levels increased significantly and protein $\mathrm{C}$ levels decreased. D-dimer, fibrinogen and soluble fibrin levels changed to a lesser extent, depending on the time spent on hemodialysis. According to these indicators, patients who were on hemodialysis for more than 15 years differed from those who were on hemodialysis for up to 5 years by $13-40 \%$.

It was found that the lack of residual renal function also significantly affected the severity of disorders in the hemostasis system. It was found that in persons with no residual renal function compared with the presence of RRF probably increased levels of fibrinogen, soluble fibrin, D- dimer and FIFP and decreased levels of protein C. Analysis of disorders in the hemostasis system depending on the presence of $\mathrm{AH}$ showed that levels of soluble fibrin and $\mathrm{D}$ dimers are clearly associated with its presence, ie their concentrations were $13-58 \%$ higher than in individuals without $\mathrm{AH}$. According to other indicators in the hemostasis system, no correlations were found with the presence of $\mathrm{AH}$.

\section{Discussion}

Thus, the study found that disorders of the hemostasis system in patients with CKD stage VD are detected in $95.5 \%$ of cases, while in the control group - only in $45.0 \%$. Regarding the frequency of disorders in the hemostasis system, the most frequent were high levels of $\mathrm{sF}-68.2 \%$ and hyperfibrinogenemia - $64.7 \%$, less often - protein C deficiency $-56.8 \%$ and the presence of FIFP - $45.5 \%$. High levels of D-dimer were found in $20.5 \%$ of people.

Literature data also indicate that patients with end-stage renal disease are activated by markers of hemostasis, namely D-dimer, soluble fibrinogen and hyperfibrinogenemia, which occur in 2/3 of patients [15]. According to Milburn J. A. [11], patients with CKD have more than a threefold increase in serum D-dimer compared with patients in the control group. According to Meamar R. [9], in children with end-stage renal disease who underwent 
regular dialysis treatment, there is a clear imbalance in the blood coagulation system, characterized by hyperfibrinogenemia and decreased serum protein $C$ compared to healthy patients. According to Japanese researchers, protein $\mathrm{C}$ deficiency and hyperfibrinogenemia were found in $28 \%$ and $37 \%$ of patients without CKD stage [4]. A significant imbalance in the markers of coagulation and fibrinolysis in patients on hemodialysis has been reported in a number of other studies [1, 13]. At the same time, there are other studies that show that with the progression of renal failure (CKD stage 1-4) there was a significant increase in coagulation markers - fibrinogen, coagulation factor VIII, D-dimer, and a decrease in antithrombin III, but they do not acquire statistical value [12].

We have shown that hemostasis disorders are more common in patients with no RRF, long history of hemodialysis, the presence of $\mathrm{AH}$ and have virtually no connection with sex, age of patients, and the presence and degree of anemia. Only one study has been found in the literature indicating that age $>65$ years was independently associated with D-dimer positive in hemodialysis patients [3].

Thus, the course of the disease, namely the absence of RRF, long experience in hemodialysis and the presence of

\section{References}

[1] Costa, E., Rocha, S., Rocha-Pereira, P., Castro, E., Reis, F., Teixeira, F., ... \& Santos-Silva, A. (2008). Cross-talk between inflammation, coagulation/fibrinolysis and vascular access in hemodialysis patients. J. Vasc. Access., 9(4), 248-253. https:/ /doi.org/10.1177/112972980800900405

[2] Dohlback, B., \& Villoutreix, B. O. (2005). Regulation of blood coagulation by the protein $C$ anticoagulant pathway: Novel Insights Into Structure-Function Relationships and Molecular Recognition. Arterioscler. Thromb. Vasc. Biol., 25(7), 13111320. doi: 10.1161/01.ATV.0000168421.13467.82

[3] Gubensek, J., Lolic, M., Ponikvar, R., \& Buturovic-Ponikvar, J. (2016). D-dimer levels in maintenance hemodialysis patients: High prevalence of positive values also in the group without predisposing diseases. Hemodial Int., 20(2), 198-203. doi: 10.1111/hdi.12371

[4] Ichinose, M., Sasagawa, N., Chiba, T., Toyama, K., Kayamori, Y., \& Kang, D. (2019). Protein C and protein S deficiencies may be related to survival among hemodialysis patients. $B M C$ Nephrol., 20(1), 191. doi: 10.1186/s12882-019-1344-8

[5] Komisarenko, S. V. (2017). Research of molecular mechanisms of thrombosis and creation of hemostatic agents. Visn. Nac. Acad. Nauk Ukr., 3, 38-44. ISSN 1027-3239

[6] Lugovskoy, E. V., Gritsenko, N. G., Lugovskaya, N. E., Kolesnikova, I. N., \& Komisarenko, S. V. (2006). Soluble fibrin. Molecular structure and quantification. Laboratory diagnostics, 3(37), 11-17.

[7] Lugovskoy, E. V., Kolesnikova, I. N., Lugovskaya, N. E., Gritsenko, P. G., Litvinova, L. M., Gogolinskaia, G. K., ... \& Komisarenko, S. V. (2006). Soluble fibrin and D-dimer at normal pregnancy and pregnancy with risk miscarriage. Ukr. Biochem. Zhurn., 78(4), 120-129. Retrieved from https:// pubmed.ncbi.nlm.nih.gov/17236629/

[8] Lugovskoy, E. V., Komisarenko, S. V., Platonova, T. M., Rublenko, A. M., Fishchenko, V. O., \& Kolesnikova, I. M. (2013). Determination of soluble fibrin and D-dimer content for
$\mathrm{AH}$ may be important pathogenetic factors that initiate disorders of the hemostasis system in patients with CKD stage VD, who are on program hemodialysis, and, obviously, may be factors in the activation of thrombotic complications in this category of patients.

A comprehensive study of the main links of hemostasis in patients with CKD stage VD expands the possibilities of preventive measures to prevent thrombophilia.

\section{Conclusions}

1. In patients with CKD stage VD, who are treated with programmed hemodialysis, in $95.5 \%$ of cases there are violations of hemostasis. The most common are high levels of SF - $68.2 \%$ and hyperfibrinogenemia - $64.7 \%$, less often - protein C deficiency - $56.8 \%$ and the presence of FIFP - $45.5 \%$. High levels of D-dimer are registered in $20.5 \%$ of people.

2. Disorders of the hemostasis system are closely associated with the absence of RRF, long history of hemodialysis and the presence of $\mathrm{AH}$ and have virtually no connection with sex, age and the presence of anemic syndrome.

prediction of thrombotic complications by hip arthroplasty. Laboratory diagnostics, 2(64), 3-8. Retrieved from http:// nbuv.gov.ua/UJRN/labdiag_2013_2_2

[9] Meamar, R., Shafiei, M., Abedini, A., Ghazvini, M. R., Roomizadeh, P., Taheri, S. \& Gheissari, A. (2016). Association of E-selectin with hematological, hormonal levels and plasma proteins in children with end stage renal disease. Adv. Biomed. Res., 29(5), 118. doi: 10.4103/2277-9175.186992

[10] Melnik, A. A. (2016). The hemostatic system and its regulation in case of impaired renal function. News of medicine and pharmacy in Ukraine, 9(583), 24-31. doi: 10.22141/23071257.3.17.2016.76541

[11] Milburn, J. A., Ford, I., Mutch, N., Fluck, N., \& Brittenden, J. (2013). Thrombin-Anti-Thrombin Levels and Patency of ArterioVenous Fistula in Patients Undergoing Haemodialysis Compared to Healthy Volunteers: A Prospective Analysis. PLoS One, 8(7), e67799. doi: 10.1371

[12] Muslimovic, A., Rasic, S., Tulumovic, D., Hasanspahic, S., \& Rebic, D. (2015). Inflammatory Markers and Procoagulants in Chronic Renal Disease Stages 1-4. Med. Arch., 69(5), $307-$ 310. doi: 10.5455/medarh.2015.69.307-310

[13] Nunns, G. R., Moore, E. E., Chapman, M. P., Moore, H. B., Stettler, G. R., Peltz, E., ... \& Sauaia, A. (2017). The hypercoagulability paradox of chronic kidney disease: The role of fibrinogen. Am. J. Surg., 214(6), 1215-1218. doi: 10.1016/j.amjsurg.2017.08.039

[14] Platonova, T. N., Zaichko, N. V., Chernyshenko, T. M., Gornitskaya, O. V., \& Grischuk, V. I. (2010). Assessment of the informative value and prognostic value of traditional screening and additional laboratory tests for the diagnosis of thrombophilia. Laboratory diagnostics, 4(54), 3-10.

[15] Popova, J. A., Yadrihinskaya, V. N., Krylova, M. I., Sleptsova, S. S., \& Borisova, N. V. (2016). Comparison of clinical and laboratory parameters in patients with end-stage renal failure in the outcome of chronic glomerulonephritis and patients with 
end-stage renal failure in the outcome of other diseases. Wiad Lek., 69(6), 739-741. Retrieved from https:// pubmed.ncbi.nlm.nih.gov/28214807/

[16] Shevchuk, S. V., Gornytska, O. V., Chernyshenko, T. M., Krasnobryzha, E. M., Korolyova, D. S., Chernyshenko, V. O., \& Platonova, T. M. (2010). Comprehensive diagnosis of thrombophilia in systemic lupus erythematosus. Laboratory diagnostics, 1(51), 3-7. Retrieved from https:// biocherv.ucoz.com/publ/

[17] Storozhuk, L. O., Shevchuk, S. V., Storozhuk, B. G., Zaichko, N. V., Lugovskoy, E. V., Platonova, T. M., ... \& Storozhuk, N. V. (2017). Clinical and laboratory diagnosis of thrombophilia in patients with XXH VD stage on program hemodialysis: guidelines. Vinnytsia: FOP Rogalska I.O. Retrieved from https:/ /dspace.vnmu.edu.ua/123456789/2933

[18] Storozhuk, O. B., Seleznyova, I. B., Storozhuk, L. O., Storozhuk,
B. G., \& Dovgalyuk, T. V. (2018). Predictors of thrombogenesis by the state of pro- and anticoagulant components of haemostasis in the patients with stage VD chronic kidney disease. Wiad Lekarsk., 71(3), cz II, 683-687. Retrieved from https://pubmed.ncbi.nlm.nih.gov/29783247/

[19] Storozhuk, O. B., Seleznyova, I. B., Storozhuk, L. O., Gornitskaya, O. V., Storozhuk, B. G., \& Slominsky, A. Yu. (2017). Functionally inactive forms of prothrombin and fibrinogen levels as markers of hypercoagulation in patients with chronic stage VD kidney disease who are on programmed hemodialysis. Reports of Vinnytsia National Medical University, 21(2), 45053. Retrieved from http://nbuv.gov.ua/UJRN/ vvnmu_2017_21_2_20

[20] Volkov, G. L., Platonova, T. N., Savchuk, A. M., Gornitskaya, O. V., Chernyshenko, T. M., \& Krasnobryzha, E. M. (2005). Modern ideas about the hemostatic system. Kiev: Scientific thought.

\section{ОСОБЛИВОСТІ ПОРУШЕНЬ ГЕМОСТАЗУ У ХВОРИХ ХХН УД СТАДІЇ ТА ЇХ ЗВ'ЯЗОК З ПЕРЕБІГОМ ЗАХВОРЮВАННЯ}

Сторожук О. Б., Шевчук С. В., Сторожук Л. О., Довгалюк Т. В., Сторожук Б. Г.

Порушення в системі гемостазу, які призводять до розвитку тромбозів, є одними із основних ускладнень хворих хронічною хворобою нирок (XXH) VД стадії, що перебувають на програмному гемодіалізі. Розвиток тромбофілічного синдрому, як процесу внутрішньосудинного згортання, характеризується системною активацією прокоагулятивних механізмів, які не завжди компенсуються за рахунок внутрішніх природних антикоагулянтних систем. Визначення ранніх предикторів можливого тромбогенезу у досліджуваної категорії хворих викликає значні труднощі. Мета - вивчити особливості порушень системи гемостазу у хворих XXH VД стадії, які перебувають на програмному гемодіалізі, та оцінити їх зв'язок з особливостями перебігу захворювання. У 88 хворих XXН VД стадії, які перебувають на програмному гемодіалізі (52 чоловіки та 36 жінок), досліджено особливості порушень гемостазу залежно від клінічних характеристик пацієнтів. Визначали показники передтромбозу (розчинний фрібрин (рФ), фрібриноген (Ф2), фрункціонально неактивні фрорми протромбіну (ФНФП)), післятромбозу (Д-димер (Д-д)) та антикоагуляції (протеїн С (рС)) залежно від статі, гемодіалізного стажу, віку, наявності анемії, артеріальної гіпертензії (АГ) та збереженої залишкової функції нирок (ЗФН). Статистична обробка матеріалів проведена з використанням методів варіаційної статистики за допомогою t-критерія Ст'юдента. Встановлено, що порушення в системі гемостазу виявляються практично у всіх хворих. При цьому, найчастіше спостерігається гіперфібриногенемія, збільшення концентрації рФ, дефіцит рС, рідше - накопичення ФНФП та високі рівні Д-д. Зазначені порушення гемостазу частіше виявляються у хворих з відсутньою ЗФН, великим стажем перебування на гемодіалізі, наявністю артеріальної гіпертензії і менше асоційовані зі статтю, віком пацієнтів та мало залежні від ступеня анемії. Ключові слова: XXH VД стадії, гемодіаліз, гемостаз, розчинний фрібрин, Д-димер, фрібриноген, протеїн С, функціонально не активні форми протромбіну.

\section{ОСОБЕННОСТИ НАРУШЕНИЙ ГЕМОСТАЗА У БОЛЬНЫХ ХБП УД СТАДИИ И ИХ СВЯЗЬ С ТЕЧЕНИЕМ ЗАБОЛЕВАНИЯ Сторожук А. Б., Шевчук С. В., Сторожук Л. А., Довгалюк Т. В., Сторожук Б. Г.}

Нарушения в системе гемостаза, приводящие к развитию тромбозов, являются одними из основных осложнений у больных хронической болезнью почек (ХБП) VД стадии, находящихся на программном гемодиализе. Развитие тромбофилического синдрома, как процесса внутрисосудистого свертывания, характеризуется системной активацией прокоагулятивных механизмов, которые не всегда компенсируются за счет внутренних природных антикоагулянтных систем. Определение ранних предикторов возможного тромбогенеза у исследуемой категории больных вызывает значительные трудности. Цель - изучить особенности нарушений системы гемостаза у больных ХБП VД стадии, находящихся на программном гемодиализе, и оценить их связь с особенностями течения заболевания. У 88 больных ХБП VД стадии, находящихся на программном гемодиализе (52 мужчин и 36 женщин), исследованы особенности нарушений гемостаза в зависимости от клинических характеристик пациентов. Определялись показатели предтромбоза (растворимый фрибрин (рФ), фрибриноген (Ф2), функционально неактивные формы протромбина (ФНФП)), посттромбоза (Д-димер (Д-д)) и антикоагуляции (протеин C (pC)) в зависимости от пола, гемодиализного стажа, возраста, наличия анемии, артериальной гипертензии (АГ) и сохраненной остаточной функции почек (ОФП). Статистическая обработка материалов проведена с использованием методов вариационной статистики с помощью t-критерия Стьюдента. Установлено, что нарушения в системе гемостаза выявляются практически у всех больных. При этом, чаще всего наблюдается гиперфибриногенемия, увеличение концентрации $р \Phi$, дефицит $p C$, реже - накопление ФНФП и высокие уровни Д-д. Указанные нарушения гемостаза чаще обнаруживаются у больных с отсутствующей ОФП, большим стажем пребывания на гемодиализе, наличием артериальной гипертензии и меньше ассоциированы с полом, возрастом пациентов и мало зависят от степени анемии.

Ключевые слова: ХБП VД стадии, гемодиализ, гемостаз, растворимый фрибрин, Д-димер, фрибриноген, протеин С, функционально не активные формы протромбина. 